\title{
WHAT DISTINGUISHES CONNOISSEURS FROM SPENDERS? A CASE STUDY OF WINE IN CROATIA
}

\author{
Anita Silvana Ilak Peršurić1 ${ }^{1}$ Stefan Mann², \\ *Corresponding author E-mail: anita@iptpo.hr
}

\begin{tabular}{l} 
A R T I C L E I N F O \\
Original Article \\
Received: 18 April2019 \\
Accepted: 10 October 2019 \\
doi:10.5937/ekoPolj1904929I \\
UDC 663.221(497.5) \\
\hline
\end{tabular}

Keywords:

Connoisseurs, spenders, wine, Croatia.

JEL: D12, Q19

\begin{abstract}
A B S T R A C T
This paper had a goal to explore the knowledge and spending power, which frequent criteria are for target groups, although they are rarely distinguished in a systematic way. This paper develops motivation for a thorough distinction and reveals differences among connoisseurs and spenders within the Croatian wine market. A theoretical model of the two target groups in a framework around the BCG matrix was developed. For the empirical verification, standardized face-to-face interviews were conducted with 307 Croatian wine consumers. For the sake of knowledge, both self-reported and observed measures were used. Our findings confirm that Connoisseurs emphasize particularly functional characteristics of wine that constitute self-related items such as self-fulfillment and social values, while spenders rather emphasize the gastronomy experience of wine. The difference between connoisseurs and spenders can be translated into marketing strategies that emphasize different product attributes and characteristics of wine at different stages of the product life cycle.
\end{abstract}

(C) 2019 EA. All rights reserved.

\section{Introduction}

Marketing science rests on the notion that different segments of consumers require different approaches (Wedel and Kamakura, 2012). Among the many segments, those who have been strongly exposed to the product under scrutiny usually receive the strongestattention. Thach and Olson(2015), for example, describe systematic differences between heavy wine users and the remaining segments in terms of sociodemographic characteristics. Therefore, Fattorini (1994), similar to Frochot (2000;p.5), suggests a 'strategy to create a small but loyal group of highly knowledgeable (invariably affluent) consumers'

1 Anita Silvana Ilak Peršurić, Ph.D., Scientific advisor, Institute for Agriculture and Tourism, C. Hugues 8, Poreč, Croatia, Phone:+38552408329, e-mail:anita@iptpo.hr, https://orcid. org/0000-0001-5234-7602

2 Stefan Mann, Ph.D., Full Professor, Agroscope, Tanikon 1, Aadorf, Switzerland, Phone:+41584803131, e-mail: stefan.mann@agroscope.admin.ch, https://orcid.org/00000003-3654-8644

http://ea.bg.ac.rs 
This paper aims to achieve a stronger differentiation among the segment of heavy users. While connoisseurs and spenders are grouped into one segment in the papers referenced above, several scholars name connoisseurs (McAnley and Leskovec, 2013, Banting et al., 2015) and spenders (Moufakkir et al., 2004, Legohérel and Wong, 2006, Kruger et al., 2015) separately. However, as far as the authors are aware, a thorough distinction between the two groups is missing. A thought developed by Lindholm et al. (2015,p. 542) for online marketing likely comes closest to such a distinction, they propose that 'Campaigns directed to spenders should enable easier spending or provide financial incentives to increase spending. Campaigns directed to engagers should focus on content creation and attraction of new customers'. Such a distinction between individuals engaged in the subject — or connoisseurs - and spenders is only useful from a marketing perspective in the event that the two segments fulfil different functions in the product life cycle.

By building on the idea by Lindholm et al. (2015) cited above, this claim is supported by a theoretical model in section theoretical background. Section materials and methods describes the methodology with which the difference in characteristics between connoisseurs and spenders is tested empirically, whose results are displayed in section research results. Finally, the last section brings concluding remarks and confirms the set arguments.

\section{Theoretic background}

\section{A BCG framework of connoisseurs and spenders}

In spite of repeated criticisms (Drews, 2008), the BCG matrix remains one of the most influential theoretical models in marketing science both in textbooks (Kotler and Keller, 2016, Schürmann, 2016) and in research (Gite and Kumar Roy, 2014, Tao and Shi, 2016, Suksantilap et al., 2017). In a review paper, Madsen (2017) describes both the enormous impact of the model and its fading popularity in the academic world, emphasising today's practical relevance of the model.

The BCG matrix was developed by Hedley (1977, p.9.), who argued that 'the relative competitive position and growth are the two fundamental parameters which must be considered in determining the strategy that an individual business should follow when viewed within the context of the company's overall "business portfolio". The model argues that focusing on the expansion of the market share is useful in the early stage of a product life cycle, whereas the main challenge in a later stage involves maintaining the high market share in times of low business growth.

Even in papers using the BCG matrix framework that focus on the identification of appropriate target groups (Vrontis et al., 2006, Nissen, 2019), the various stages of the product life cycle are typically not connected with a change in target groups. This may be considered a conceptual omission when more closely observing the single steps of product development. 


\section{Creating awareness for developing stars}

More than 50 years ago, Murphy (1962, p. 49) named communication-one of the core success factors when handling new products- 'the greatest potential source of trouble in product programmes'. During a stage wherein the greatest obstacle for higher sales numbers is that consumers are unaware of a product, it is crucial that multiplicatorsindividuals who spread news of a product's existence - be approached.

However, if information is the bottleneck of sales growth, one must identify the appropriate multiplicators within the market. For the creative industry, for example, Lange (2018) identifies fashion label owners and gallery owners as multiplicators, whereas financial journalists and tax consultants have been identified as multiplicators when branding financial services (Degener, 1999, Fritton, 2004).

In both cases, multiplicators are individuals with greater cognitive and emotional engagement and therefore more profound knowledge of the respective market than average consumers. For this reason, multiplicators are often labelled as the most appropriate target group in general (McAuley and Leskovec, 2013) as well as in terms of innovative products in particular (Kawamae, 2015).

This creates the necessity that connoisseurs be focused on during the early stages of a product life cycle. A market's connoisseurs are most likely trustworthy and available to give advice as well as generate attention when sharing their consumption experiences. Therefore, connoisseurs should be the main target groups for strategies to increase the market share.

\section{Broadening the buyer base}

Once a product is established in the market and is later widely known, it is questionable how much attention should be paid to spreading the product's information on a broad scale. If cash cows are to be generated, the most likely target group is the group with the most cash. Frascarelli (2005) gives a prominent example of a strategy that involves focusing on spenders to attract the attention of consumers who matter. In any case, approaching and convincing a consumer who spends $100 €$ per month contributes ten times the value to sales targets as does approaching and convincing a consumer with a monthly expenditure of $10 €$.

All these factors indicate that target groups should change over time, as illustrated in Figure 1. In the beginning of a product life cycle, multiplicators should be actively approached, people with some authority due to their knowledge and engagement. This will be the most effective way to broaden the buyer base and thus increase the market share. 
Figure 1. A BCG model of different target groups

Market Share

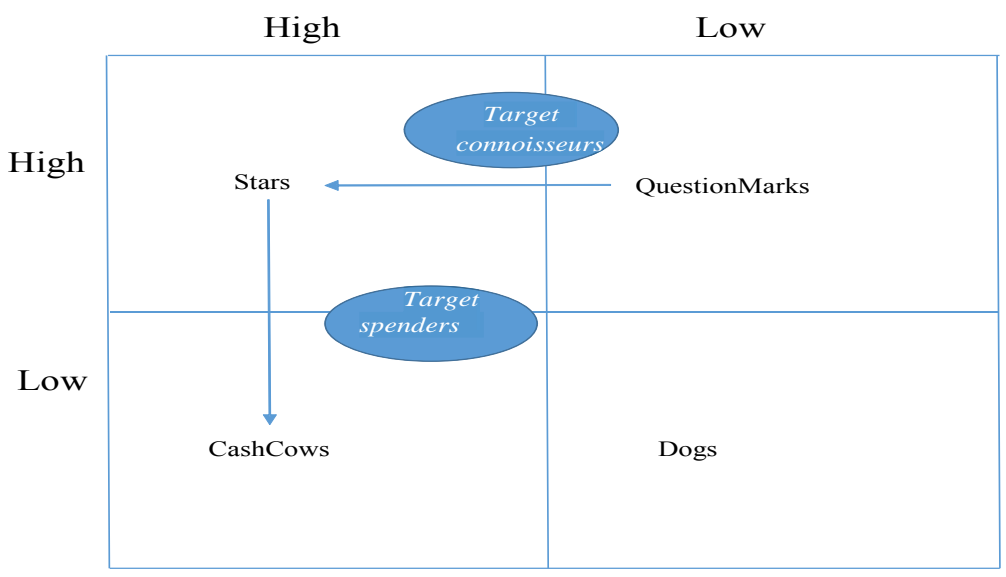

Source: Authors' model created according to Hedley (1977)

Putting this principle into practice, however, requires that connoisseurs and spenders be distinguishable by their sociodemographic characteristics, tastes, or preferences. Whether or not this distinction is empirically possible will be explored in the following section.

\section{Materials and methods}

\section{Research settings}

This paper was founded upon on a survey conducted as a part of project "MalvasiaTourIstra" financed by Operational Programme Slovenia-Croatia 2007-2013. The target population included Croatian wine consumers who were 18 years of age or older. Wine consumers were approached by trained researchers and asked to participate in the survey. The researchers explained that the survey was anonymous and the purpose of the survey. In the process of on-site data collection responders were mobile while researchers were stationary (Veal, 2006). A convenient sample was used. The self-complete questionnaires were administered by researchers and 307 validated questionnaires were collected. The survey was executed during 2015. The survey contained a broad range of questions on wine as well as wine's social and other functions.

The goals of the research were a) to detect differences between two groups of wine consumers considering expenses for wine; b) to detect differences in the level of wine knowledge; c) to detect differences in motives for wine consumption. We presumed that wine consumers can be identified in two different groups; connoisseurs and spenders. We are led to the old dichotomy of observation versus self-declaration described by Kendall et al. (2004) and Freedman et al. (2018). These authors illustrated that self-declarations may lead to results very different than those achieved by external observations. Going beyond past reliance on self-declared knowledge, as discussed by Sellers-Rubio and Nicolau-Gonzalbez (2016), it would therefore be useful to 
additionally include measures based on observations. In our research amounts spent on wine per month were self declared and the only dependent variable for identifying spenders. A self-reported variable was also used for knowledge aspects. In addition, however, we assumed wine event attendees would more likely be connoisseurs than would consumers approached in their homes; for this reason, the interview location was used as a dependent variable. Taking the considerations above together, our hypothesis was that wine spenders are a different group compared to wine connoisseurs considering the attributes they connect with wine and the occasions when they consume wine.

The choice of the independent variables was guided by the underlying hypotheses. Because both knowledge and wage may rise over the life course, it was hypothesised that age will be positively correlated with all dependent variables. Income, however, was likely to be connected with spending volume but not with knowledge.

Based on the findings by Dodd et al. (2010) which states that 'the sweet segment is younger, less well-educated, less involved with the product category and less informed about wine, the preference for dry wine is one of the factors we expect to be connected to knowledge rather than income.

The motivations of wine drinking will, in general, have a strong impact on both becoming an expert as well as the amount spent on wine. Based on Meler et al. (2016) and Ilak Persuric et al. (2018), we considered self-fulfilment one of the forces that could contribute to an individual concerning oneself with wine in terms of spending money, but even more so in terms of collecting wine-related knowledge. Therefore, we hypothesised that self-fulfilment experienced while drinking wine will be positively related to all three dependent variables.

It was apparent how strongly family cultures influence our lives (Ticknell, 2005), this also applies to wine consumption (Ritchie, 2009). Therefore we utilised this fact through two different variables, both of which inquired as to the influence of family tradition and the use of wine as a bond between generations. These cultural factors are unlikely to affect spending behaviour.

Table 1. Descriptive Statistics

\begin{tabular}{|c|c|c|c|}
\hline Variables & Explanations & Scales & Mean \\
\hline \multicolumn{4}{|c|}{ Dependent Variables } \\
\hline Wine event & $\begin{array}{r}\text { Interview conducted at a } \\
\text { wine event }\end{array}$ & - No; 1 - Yes & 0.67 \\
\hline Knowledge & $\begin{array}{l}\text { Agreement to 'I believe I } \\
\text { have knowledge of wine' }\end{array}$ & $\begin{array}{r}\text { Likert scale from } 1 \text { (I do not agree } \\
\text { at all) to } 5 \text { (I agree totally) }\end{array}$ & 2.91 \\
\hline Expenses & Monthly wine expenses & $\begin{array}{r}1:<20 € \\
2: 21-35 € \\
3: 36-55 € \\
4:>55 €\end{array}$ & 1.91 \\
\hline \multicolumn{4}{|c|}{ Independent Variables } \\
\hline Age & Respondent's Age & Years & 37.93 \\
\hline
\end{tabular}




\begin{tabular}{|c|c|c|c|}
\hline Variables & Explanations & Scales & Mean \\
\hline Income & $\begin{array}{r}\text { Monthly net household } \\
\text { income }\end{array}$ & $\begin{array}{r}1:<1000 € \\
2: 1000-2000 € \\
3: 2001-3000 € \\
4: 3001-4000 € \\
5:>4001 €\end{array}$ & 2.80 \\
\hline Dry wine & Preference for dry wine & $\begin{array}{r}1-\text { dry } 2-\text { semi dry } \\
\text { 3- semisweet } 4-\text { sweet }\end{array}$ & 0.98 \\
\hline Self-fulfilment & $\begin{array}{r}\text { Self-fulfilment as a reason } \\
\text { to drink wine }\end{array}$ & $\begin{array}{r}\text { Likert scale from } 1 \text { (I do not agree } \\
\text { at all) to } 5 \text { (I agree totally) }\end{array}$ & 2.96 \\
\hline Family tradition & $\begin{array}{l}\text { Family tradition as a } \\
\text { reason to drink wine }\end{array}$ & $\begin{array}{r}\text { Likert scale from } 1 \text { (I do not agree } \\
\text { at all) to } 5 \text { (I agree totally) }\end{array}$ & 2.43 \\
\hline Bond of generations & $\begin{array}{r}\begin{array}{r}\text { Wine is a bond of family } \\
\text { generations }\end{array} \\
\end{array}$ & $\begin{array}{r}\text { Likert scale from } 1 \text { (I do not agree } \\
\text { at all) to } 5 \text { (I agree totally) }\end{array}$ & 3.23 \\
\hline Ambience & $\begin{array}{l}\text { Wine creates special } \\
\text { cosiness and ambience }\end{array}$ & $\begin{array}{r}\text { Likert scale from } 1 \text { (I do not agree } \\
\text { at all) to } 5 \text { (I agree totally) }\end{array}$ & 3.66 \\
\hline Time of my own & $\begin{array}{r}\text { Wine gives me time of my } \\
\text { own }\end{array}$ & $\begin{array}{r}\text { Likert scale from } 1 \text { (I do not agree } \\
\text { at all) to } 5 \text { (I agree totally) }\end{array}$ & 3.10 \\
\hline Gastronomy experience & $\begin{array}{l}\text { Wine offers a complete } \\
\text { gastronomy experience }\end{array}$ & $\begin{array}{r}\text { Likert scale from } 1 \text { (I do not agree } \\
\text { at all) to } 5 \text { (I agree totally) }\end{array}$ & 4.13 \\
\hline Thirst & Wine is good for thirst & $\begin{array}{r}\text { Likert scale from } 1 \text { (I do not agree } \\
\text { at all) to } 5 \text { (I agree totally) }\end{array}$ & 3.72 \\
\hline New experience & $\begin{array}{r}\text { Wine provides the } \\
\text { possibility of new } \\
\text { experiences }\end{array}$ & $\begin{array}{r}\text { Likert scale from } 1 \text { (I do not agree } \\
\text { at all) to } 5 \text { (I agree totally) }\end{array}$ & 3.31 \\
\hline
\end{tabular}

Source: authors' calculations based on field research

However, consumption behaviour and consuming knowledge was known to be strongly influenced by psychographic traits, subjective knowledge and family income (Pomarici et al. 2017).Two variables that emphasised the affective component of wine were included. Ambience, while particularly emphasised in the context of wine tourism (Getz et al., 1999, Bruwer and Leschaeve, 2012), may be an important attribute that motivates both knowledge generation and purchasing actions. However, consumers who do not prioritise wine as a social tool, but rather use it for self-enjoyment, appear more likely to inform themselves more thoroughly and spend more on wine.

The next variable directed the attention towards a wine's innovative function. If new experiences were sought while individuals drink wine, the cognitive element of information seeking rather than the amount spent was likely to play an important role.

Wine possesses different social and culinary functions, and as such, wine drinking may be considered a culinary experience in itself. Alternatively, wine may also be considered an instrument to increase the enjoyment of food consumption. Warde and Martens (2000) demonstrated that restaurants were particularly prone to such acts of pleasure. Consumers with this attitude towards wine were hypothesised as being less likely to 
have thorough knowledge of wine. Due to the extra margins that must be paid for wine served in restaurants, however, this group was likely to spend larger amounts on wine. We expected negative signs for the 'Thirst' variable; if wine was hardly considered a way to quench one's thirst, then consumers were likely to neither gather knowledge of wine nor purchase expensive bottles.

A logit analysis was used to explain the three dependent variables, the interview location, and the ordered logit in the case of the two self-statements on a multinomial scale. Stata 14 programme was used for the calculation.

\section{Research results}

The average replies for each single item, which are worth comparing with the different functions of wine are displayed in Table 1. Wine is rarely considered a family tradition, and the agreement of wine as a provider of self-fulfilment is also rather low. It is acknowledged, however, that wine serves as an enjoyable complement of gastronomy and quenches thirst.

The level of wine knowledge and expenditures is explained through results presented in Table 2. The left columns provide results for the two knowledge-related variables. The lower share of variance that may be explained by using self-stated knowledge compared to the observation variable (location of the interview) may have occurred due to many reasons. It is possible, however, that large amounts of noise make selfstated knowledge quite unreliable. Some respondents may live in a very well-informed environment and may therefore underestimate their own level of knowledge, whereas other respondents may wish to brag. Being on a wine event may be a more effective indicator for distinguishing connoisseurs from others.

As often, it is not only interesting to see significances, but also missing ones where they would have been expected. This applies, for example, to age; apparently, neither the level of knowledge nor the amount spent on wine significantly correlates with age.

Another noteworthy insignificance is the relationship between income and expenses. It seems wine does not cover a sufficiently large part of consumer budget to be steered by the latter's absolute level. However, a surprising result is that wine event attendees generally earned less than consumers who were interviewed in their households.

A hypothesis that may be clearly confirmed is the preference of dry wine among connoisseurs not according to self-ratings, but rather according to observations. In addition, consumers who spend larger amounts on wine tend to prefer dry wine, albeit at a lower degree.

When observing the following variables, a general tendency was the stronger importance placed on functional characteristics by connoisseurs compared to spenders.

Self-fulfilment was a motivation to drink wine and relevant for both connoisseurs and spenders - although more so for the former group. The fact that wine facilitates 
a bond between generations and provides time for both the self and new experiences was important to connoisseurs rather than spenders. A particularly striking case was the role of cosiness and ambience, which matters to those who claim to know much about wine, although it was negatively significant regarding the monetary amount spent on wine. While the appreciation of the wine-drinking atmosphere seemed to be important for gathering knowledge on wine, low-priced wine seemed to function as sufficiently for this purpose in the same way as high-priced wine.

Table 2. Regression Results

\begin{tabular}{|l|r|r|r|}
\hline & Wine event & Knowledge & Expenses \\
\hline Age & $-0.002(0.894)$ & $0.017(1.58)$ & $0.008(0.74)$ \\
\hline Income & $-0.694^{* * *}(-3.44)$ & $0.131(1.26)$ & $0.035(0.738)$ \\
\hline Dry wine & $1.715^{* * *}(3.39)$ & $-0.121(0.470)$ & $0.466^{* *}(2.57)$ \\
\hline Self-fulfilment & $1.257^{* * *}(3.21)$ & $0.198(1.27)$ & $0.368^{*}(2.15)$ \\
\hline Family tradition & $0.266(1.28)$ & $-0.008(-0.07)$ & $-0.126(-0.12)$ \\
\hline Bond of generations & $0.522^{*}(2.24)$ & $0.344^{* *}(2.67)$ & $-0.090(-0.68)$ \\
\hline Ambience & $0.068(0.29)$ & $0.534^{* * *}(3.71)$ & $-0.281^{*}(-1.96)$ \\
\hline Time of my own & $0.460^{*}(2.04)$ & $-0.066(-0.56)$ & $0.111(0.93)$ \\
\hline New experience & $0.424^{*}(2.05)$ & $0.177(1.31)$ & $-0.148(-0.11)$ \\
\hline Gastronomy experience & $-0.900^{* *}(-2.72)$ & $0.182(1.06)$ & $0.425^{*}(2.39)$ \\
\hline Thirst & $-0.886^{*}(-2.40)$ & $-0.150(-1.27)$ & $-0.068(-0.57)$ \\
\hline Pseudo-R $\mathrm{R}^{2}$ & 0.47 & 0.11 & 0.06 \\
\hline
\end{tabular}

z-value in parentheses; $* \mathrm{p} \leq 0.05 ; * * \mathrm{p} \leq 0.01 ; * * * \mathrm{p} \leq 0.001$

\section{Source: authors' calculations based on field research}

Patterns changed among the two functional variables. As hypothesised, high spenders tended to emphasise the gastronomy function of wine, wherein bottles costed markedly more than those sold in the shop. On the other hand, wine event attendees didn't think highly of the gastronomical function of wine. As expected, they also rejected wine as a tool for quenching thirst.

\section{Conclusions}

By including both self-rated and observation-related variables for knowledge of wine and comparing them to the amount spent on wine, some noteworthy differences between connoisseurs and spenders were revealed. As a general tendency, it was reasonable to claim that connoisseurs emphasised rather metaphysical attributes of wines, and being related to the drinking subject (e.g., time of my own or self-fulfilment) or the community (e.g., bond of generations), while spenders, on the other hand, rather prioritised gastronomical experiences with wine.

Taken together with the theoretical framework developed above, these results allow for a clearer distinction between target groups. Multiplicators who know more about the subject than others should be approached during the earlier stage of the product life cycle. The empirical results demonstrate that the functional characteristics of wine 
provide a convenient starting point for such a strategy. Emphasising both the social and self-transforming functions of wine are promising ways of getting attention by connoisseurs for advertising messages.

The recommended communication strategy changes as soon as the product has reached a stage of maturation, when it then becomes more important to target individuals spending larger amounts on wine. The results suggest that targeting these individuals through the catering chain rather than through retailing seems to provide the most promising pathway for their mobilisation.

Connoisseurs and spenders should be distinguished in strategical marketing, what is possible to accomplish due to their diverse characteristics. While this distinction has been demonstrated for wine in Croatia, there are certainly multiple products and additional regions wherein such a distinction would be equally worthwhile.

\section{Acknowledgements}

The research for this paper was conducted as a part of project financed by IPA Operational Programme Slovenia-Croatia 2007-2013, during the project "MalvasiaTourIstra" in 2014-2015. The main focus of this research was placed on wine and Malvazija Istarska as autochthonous grape and wine.

\section{Conflict of interests}

The authors declare no conflict of interest.

\section{References}

1. Banting, P.M., Blenkhorn, D.L., Kosenko, R. (2015). An Exploratory Investigation of New Product Adoption Decision Criteria Reported by Non-Food Retail Chain Buyers. In: Malhotra N. (eds) Proceedings of the Academy of Marketing Science (AMS) Annual Conference. Developments in Marketing Science, Springer, ISBN 978-3-319-11797-3

2. Bruwer, J., Lesschaeve, I. (2012). Wine tourists' destination region brand image perception and antecedents: Conceptualization of a winescape framework. Journal of Travel \& Tourism Marketing, 29(7), 611-628, doi: 10.1080/10548408.2012.719819

3. Cypryjanski, J., Grzesiuk, A., Rudawska E. (2016). The Behaviour of Inexperienced Buyers in Buy-It-Now Online Auctions. In: Nermend K., Łatuszyńska M. (eds) Selected Issues in Experimental Economics. Springer Proceedings in Business and Economics, Springer, ISBN 978-3-319-28419-4

4. Degener, M. (1999). Branding of services, with special reference to the financial service sector. Stellenbosch: University of Stellenbosch

5. Dodd, T.H., Kolyesnikova, N., Wilcox, J.B. (2010). A matter of taste: Consumer preferences of sweet and dry wines. 5th International Academy of Wine Business Research Conference, Auckland, New Zealand,http://academyofwinebusiness.com/ wpcontent/uploads/2010/04/DoddKolyesnikovaWilcox-A-Matter-of-Taste.pdf 
6. Drews, H. (2008). Abschied vom marktwachstums-marktanteils-portfolio nach über 35 jahren einsatz? Eine kritische überprüfung der BCG-matrix. Zeitschrift für Planung und Unternehmenssteuerung, 19(1), 39-57. doi.org/10.1007/s00187-0080041-8

7. Fattorini, J. (1994). Professional consumers: Themes in high street wine marketing. International Journal of Wine Marketing, 6(2), 5-13. doi.org/10.1108/eb008628

8. Frascarelli, L. (2005). 'Come back to Kendal' urge traders. The WestmorelandGazette,https://www.thewestmorlandgazette.co.uk/news/594550. display/

9. Freedman, L.P., Kujawski, S.A., Mbuyta, S., Kuwaweraruwa, A., Kruk, M.E., Ramsey, K., Mbaruku, G. (2018). Eye of the beholder? Observation versus selfreport in the measurement of disrespect and abuse during facility-based childbirth. Reproductive Health Matters, 26(53), 107-122. doi.org/10.1080/09688080.2018.1 502024

10. Fritton, M. (2004). Kommunikation und marketing für eine förderbank. In W.L. Brunner (Ed.), Erfolgsfaktoren im Bankmarketing, Wiesbaden: Gabler Verlag, ISBN 978-3-322-82491-2

11. Frochot, I. (2000). Wine tourism in France - A paradox? In C.M. Hall, B. Cambourne, L. Sharples, N. Macionis (Eds.), Wine tourism around the world. Amsterdam: Elsevier. ISBN 075065466 X

12. Getz, D., Dowling, R., Carlsen, J., Anderson, D. (1999). Critical success factors for wine tourism. International Journal of Wine Marketing, 11(3), 20-43. doi. org/10.1108/eb008698

13. Gite, P., Kumar Roy, C. (2014). Export markets' segmentation, performance and marketing of Indian carpet industry: A BCG matrix approach. Pacific Business Review, 6(11), 28-33.

14. Hedley, B. (1977). Strategy and the 'business portfolio'. Long Range Planning, 10(1), 9-15.

15. Ilak Persuric, A.S., Damijanić Težak, A., Kerma, S. (2018). The relationship between autochthonous wine attributes and wine consumption motives. Economics of Agriculture, 65(4), 1337-1357. doi:10.5937/ekoPolj1804337I.

16. Kawamae, N. (2015). Real time recommendations from connoisseurs. KDD15 Proceedings of the $21^{\text {st }}$ ACM Conference, New York, ACM, ISBN 978-1-45032404-5

17. Kendall, P.A., Elsbernd, A., Sinclair, K., Schroeder, M., Chen, G., Bergmann, V., Hillers, V.N., Medeiros, L.C. (2004). Observation versus self-report: Validation of a consumer food behavior questionnaire. Journal of Food Protection, 67(11), 2578-2586. doi.org/10.4315/0362-028X-67.11.2578

18. Kotler, P., Keller, K.L. (2016): Marketing management. New York: Pearson, ISBN139780133856460 
19. Kruger, M., A. Viljoen, M. Saayman (2015). Who are the big spenders at a motorcycle event? Journal of Economic and Financial Sciences 8 (2) 327-353.

20. Lange, B. (2018). The paradox between individual professionalization and dependence on social contexts and professional scenes. In E. Innerhofer, $\mathrm{H}$. Pechlaner, E. Borin (Eds.), Entrepreneurship in culture and creative industries. FGF Studies in Small Business and Entrepreneurship. Cham: Springer, ISBN 9783-319-65506-2.

21. Legohérel, P., Wong, K.K.F. (2006). Market segmentation in the tourism industry and consumers' spending. Journal of Travel \& Tourism Marketing, 20(2), 15-30. doi.org/10.1300/J073v20n02_02

22. Lindholm J., Kaptein, M., Parvinen, P. (2015). The price of customer engagement: How substitution in online services leads to decreasing revenues. In L. Robinson, Jr. (Ed.), Marketing dynamism \& sustainability: Things change, things stay the same.... Developments in marketing science: Proceedings of the academy of marketing science, Springer, ISBN 978-3-319-10912-1

23. Madsen, D.Ø. (2017). Not dead yet: The rise, fall and persistence of the BCG matrix. Problems and Perspectives in Management, 15(1), 19-34. doi.org/10.21511/ ppm.15(1).2017.02

24. McAnley, J.J., Leskovec, J. (2013). From amateurs to connoisseurs: Modelling the evolution of user expertise through online reviews, Proceedings of the 22nd International Conference on World Wide Web. New York: ACM, ISBN 978-14503-2038-2

25. Meler, M., Horvat, D., Kristic, J. (2016). Wine consumer traits. Journal of Agricultural, Food and Environmental Sciences, 70, 20-26.

26. Moufakkir, O., Singh, A.J., Moufakkir-van der Woud, A., Holecek, D.F. (2004). Impact of light, medium and heavy spenders on casino destinations: Segmenting gaming visitors based on amount of non-gaming expenditures. Gaming Research \& Review Journal, 8(1) https://digitalscholarship.unlv.edu/grrj/vol18/iss1/4

27. Murphy, J.H. (1962). New products need special management. Journal of Marketing, 26(4), 46-49.

28. Nissen, V. (2019). Advances in consulting research. Heidelberg: Springer, ISBN 978-3-319-95999-3

29. Pomarici, E., Lerro, M., Chrysochou, P., Vecchio, R., Krystalli A. (2017). One size (obviously not) fit all: Using product attributes for wine market segmentation. Wine Economics and policy 6:98-108. doi.org/10.1016/j.wep.2017.09.001

30. Ritchie,C.(2009). ThecultureofwinebuyingintheUKoff-trade.International Journal of Wine Business Research, 21(3), 194-211. doi.org/10.1108/17511060910985944

31. Schürmann, M. (2016). Marketing - in vier schriten zum eigenen marketingkonzept. Zürich: Hochschulverlag. ISBN 978-3-7281-3715-9 (E-Book), doi/10.3218/3715-9 
32. Sellers-Rubio, R., Nicolau-Gonzalbez, J.L. (2016). Estimating the willingness to pay for a sustainable wine using a Heckit model. Wine Economics and Policy, 5(2), 96-104.doi.org/10.1016/j.wep.2016.09.00

33. Suksantilap, P., Leelasantitham, A., Glesner, M. (2017). A survey of demand factors utilized in the facial surgery service business using BCG matrix. International Journal of Applied Biomedical Engineering, 10(2), 10-15.

34. Tao, Z.-Q., Shi, A.-M. (2016). Application of Boston matrix combined with SWOT analysis on operational development and evaluations of hospital development. European Review for Medical and Pharmacological Sciences, 20, 2131-2139.

35. Thach, L., Olsen, J. (2015). Profiling the high frequency wine consumer by price segmentation ithachn the US market. Wine Economics and Policy, 4(1), 53-59.doi. org/10.1016/j.wep.2015.04.001

36. Ticknell, E. (2005). Mediating the family: Gender, culture and representation. Bristol: Hodder Arnold, ISBN-13: 978-0340740804

37. Veal A.J. (2006). Research Methods for Leisure and Tourism: A Practical Guide. Pearson Education Limited: Essex, 1-559, ISBN 0273682008.

38. Vrontis, D., Kogetsidis, H., Stavrou, A. (2006). Strategic marketing planning for a supplier of liquid food packaging products in Cyprus. Journal of Business \& Industrial Marketing, 21(4), 250-261. doi.org/10.1108/08858620610672623

39. Warde, A., Martens, L. (2000). Eating out: Social differentiation, consumption and pleasure. Cambridge: Cambridge University Press, ISBN 9780521599696

40. Wedel, M., Kamakura, W.A. (2012). Market segmentation: Conceptual and methodological foundations. Heidelberg: Springer, ISBN 978-1-4615-4651-1

41. Wicks, B.E., Schuett, M.A. (1994). Using travel brochures to target frequent travellers and 'big-spenders', Journal of Travel \& Tourism Marketing, 2(2-3), 77-90. 